\title{
Prevalence of burnout syndrome in students at a university in northeastern Mexico
}

\author{
Daniel Cantú-Alejo ${ }^{1 *}$, Arturo Cantú-Kawas ${ }^{1}$, David Castañeda-Vásquez¹, César E. Luna-Gurrola², \\ Carlos A. López-Acevo ${ }^{3}$, and Raúl G. Salazar-Montalvo ${ }^{1}$
}

${ }^{1}$ Department of Preventive Medicine and Public Health, School of Medicine; ${ }^{2}$ Department of Microbiology, "Dr. Jose Eleuterio Gonzalez" University Hospital; ${ }^{3}$ Department of Psychiatry, "Dr. Jose Eleuterio Gonzalez" University Hospital. Universidad Autónoma de Nuevo León, Monterrey, Nuevo Leon, Mexico

\begin{abstract}
Objective: The objective of the study was to describe the prevalence of burnout syndrome (BOS) in medical students. Materials and methods: This was a cross-sectional, observational, and descriptive study. Each student was invited verbally to respond anonymously to the Maslach Burnout Inventory-Student Survey. Results: The $6^{\text {th }}$ year presented the lowest level within the $1^{\text {st }}$ percentile. On the overwhelming emotional exhaustion subscale, we found high levels in $6^{\text {th }}$ year students compared to the other years. On the feelings of cynicism subscale, there was a gradual increase, with the lowest levels within the $2^{\text {nd }}$ year to the highest levels among the $6^{\text {th }}$ year. Conclusions: It was determined that school year has an influence on the presence of BOS; although not properly what we call BOS, it affects the values of each subscale separately.
\end{abstract}

Key words: University. Fear. Stress. Anxiety. Student.

\section{Introduction}

Burnout syndrome (BOS), also known as exhaustion syndrome, is characterized by physical and mental depletion and being worn out by carrying out excessive demands, in addition to work-related stress. It was first described by Freudenberger ${ }^{1-3}$. Today, it constitutes a problem with large social repercussions ${ }^{4}$, as well as negative implications in the organizational sphere affecting different areas of personal functioning ${ }^{5}$, for which a proper and functional therapeutic intervention has not yet been determined ${ }^{6}$.

BOS is assessed mainly by a diagnostic tool which analyzes its three key dimensions: overwhelming emotional exhaustion (OEE), feelings of cynicism (FOC), and reduced personal accomplishments (RPA) ${ }^{7,8}$. OEE is about feelings of physical and psychological over-extension ${ }^{9}$, cynicism refers to a lack of empathy by professionals, and RPA refers to a decline in the feeling of work competence and success ${ }^{4}$.

The presence of student BOS is linked to the fact that academic institutions do not always enable academic performance in the university student. A few examples of this are, not providing enough resources, the practice of negative dynamics for the performance of an academic paper, and excessive demands. A BOS subtype has been defined for university students, and Shaufeli et al. created the MBI-SS (Student Survey) for this group in particular ${ }^{10}$.

Among the socio-demographic variables that affect the degree of BOS onset in medical students, an area 
highly linked to this phenomena ${ }^{11,12}$, are endogenous traits, that is, gender and personality, in addition to how long they have been studying (conferences, tutorials, and lectures), relationship status, level of social assistance, alcohol consumption, depression, or anxiety as a consequence of BOS, etc. ${ }^{13-15}$

BOS frequently occurs in health candidates and professionals, in general, those who work in healthcare organizations and who are in direct contact with people who are in a situation of dependency or need. It is known that causes of BOS are detrimental factors imposed by the same institution upon their students, that is, long shifts and a lack of work and/or academic incentives. Due to their high standards, schools of medicine represent a risk factor for BOS in students $^{16,17}$. Lisa et al. determined that the estimations of prevalence of depression or depressive symptoms among students vary according to the literature, ranging between $1.4 \%$ and $73.5 \%$, and observed that about a third of the studied subjects suffered from depression or any of its symptoms, and $11 \%$ had suicidal thoughts during their academic period within their medical career ${ }^{18,19}$.

Therefore, the objective of this study was to describe the prevalence of BOS in medical students, divided by each of the 6 academic years and 3 years of medical internship which the current academic program includes (within the $2^{\text {nd }}$ half of the academic plan), and also discovering the influence of each subscale of the MBI-SS (the three dimensions) separately on the student community's prevalence of BOS.

\section{Materials and methods}

\section{Type of study}

A cross-sectional, observational, and descriptive study was conducted in the School of Medicine of the Autonomous University of Nuevo Leon (UANL by its Spanish acronym). The study was carried out between January and June 2018. A total of 385 students completed the survey, from students in their $1^{\text {st }}$ year of medicine school to those in their $6^{\text {th }}$ year. The distribution was as follows: $1421^{\text {st }}$-year students, $542^{\text {nd }}$-year students, $513^{\text {rd }}$-year students, $484^{\text {th }}$-year students, 47 $5^{\text {th }}$-year students, and $436^{\text {th }}$-year students.

\section{Instruments}

Each student was verbally invited to respond the Maslach Burnout Inventory-Student Survey anonymously.
This tool was used to assess BOS in university students as a self-evaluation using a Likert-like 7-point scale. Once the results were obtained, BOS prevalence was analyzed and in case of having resulted positive, comparisons of the possible risk factors for presenting BOS were made in relation with those patients who suffer from it and its severity.

There are different ways to interpret these results, one of which is the use of percentiles, which was the one utilized for this study and is the most common form of results interpretation for MBI-SS ${ }^{20}$. The results of this study were used as cutting points of their variables to analyze. The obtained percentiles for each of the scales within our study were utilized for the interpretation of the MBI-SS scale (Percentile 5, 25, 50, 75 , and 95), where both ends represented abnormal data according to each of the subscales, OEE represented as OEE percentile $<25$, FOC represented as FOC percentile $>75$, and RPA represented as RPA percentile $<25$.

\section{Selection process}

Included participants were students from the medicine school who were studying in the corresponding school year (SY) regularly and who answered the MBI SS clearly and in its entirety.

\section{Analyzed variables}

Age (years), gender, residence, children, marital status, extracurricular activities, academic hours, extraordinary subjects, conference/lecturer activities, daily sleeping hours, addictive habits, use of antidepressants, subscale of MBI-SS, and presence of BOS.

\section{Statistical analysis plan}

Using the SPSS v.22 software (IBM), an analysis was conducted assisted by Cronbach's alpha to determine the internal consistency of the results. A Cronbach's alpha value between 0.70 and 0.90 indicates a good internal consistency, which means it represents an easy and reliable way to validate the questionnaire's structure, in this case, the MBI-SS, and thus quantify the correlation between its items or questions ${ }^{21}$.

In addition, a descriptive analysis was conducted to determine the values of the concerning percentiles for the interpretation of the MBI-SS. The statistical ANOVA test was used to compare the average values of the 3 


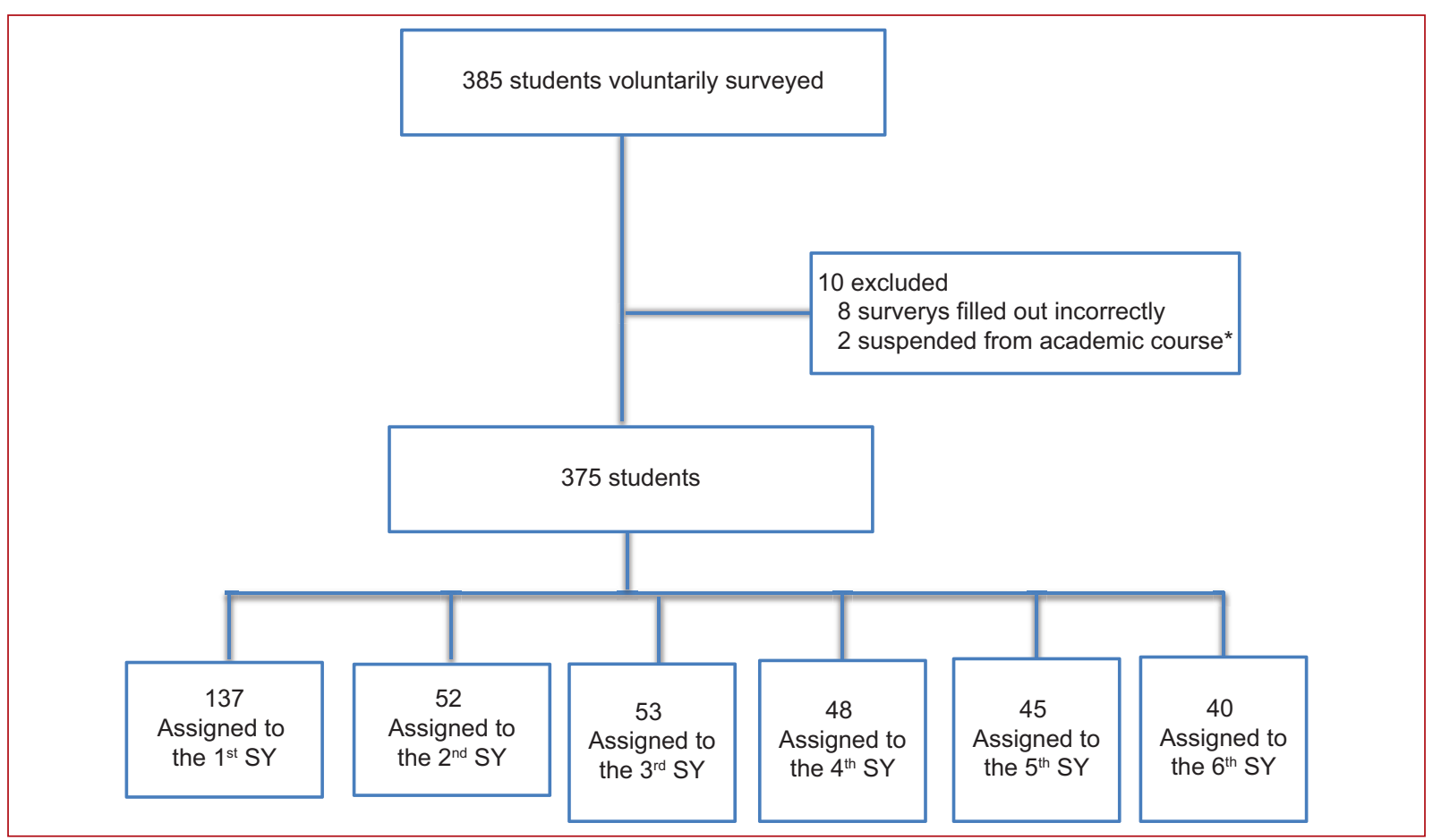

Figure 1. Essay profile. "The suspension of the academic course under any concept is considered exclusion criteria for this study, since a student who attends the school during this academic status does not necessarily follow regular activities as the average SY student does. SY: School year.

MBI-SS subscales for each academic year separately, and their statistical significance was represented by $p<0.5$. The statistical software EPIDAT v.4.2 was utilized to calculate sample size and was divided by each academic group.

\section{Results}

A total of 385 volunteers were surveyed between January and July 2018. (Fig. 1) Ten individuals were excluded, leaving 375 participants who agreed to participate in this study. Table 1 describes the frequencies and averages of the most relevant socio-demographic variables of the sample. The number of men and women varied between all the assessed SY; moreover, ages between every group grew accordingly to their SY as expected, the number of foreign students was in general lower compared to local students. In addition, the values "marital status" and "children" were eliminated, since from the entirety of our sample, only two volunteers declared having children or not being single. There was an increase in the number of students working during their $5^{\text {th }}$ and $6^{\text {th }}$ SY, and sleeping hours as well as the number of hours considered academic differed between years.
Table 2 presents a descriptive comparative between MBI-SS subscale variables divided by SY. Within the FOC subscale, there was a gradual rise in the average result of the total score of said subscale per SY in the different SYs, except in the resulting values of the first SY, which turned out to be higher only than the values of the second SY.

Table 3 describes the cutting points and values according to each academic degree. Concerning the RPA subscale, this did not present variations within any of the percentiles between the analyzed academic degrees, except in the $6^{\text {th }} \mathrm{SY}$, which presented the lowest level within the $1^{\text {st }}$ percentile and the $2^{\text {nd }}$ lowest within the last, only surpassed by the $1^{\text {st }} \mathrm{SY}$. The prevalence of BOS in total was $7 \%$ of the sample without divisions by $S Y$ at the institution.

The OEE subscale showed high levels in students of the $6^{\text {th }}$ year compared to the rest of the SYs, over the first and last percentile. There were variations between the years within the higher intermediate percentiles, like those who were in their $3^{\text {rd }}$ and $4^{\text {th }}$ SY. Obtained data regarding the FOC scale showed a gradual increase, with the lowest levels during the $2^{\text {nd }}$ SY till the $6^{\text {th }}$ SY with abnormal levels, with the exception of the $1^{\text {st }}$ SY. 
Table 1. Socio-demographic characteristics

\begin{tabular}{|c|c|c|c|c|c|c|c|}
\hline & & $\begin{array}{c}1^{\text {st }} S Y \\
(n=137)\end{array}$ & $\begin{array}{l}2^{\mathrm{do}} S Y \\
(\mathrm{n}=52)\end{array}$ & $\begin{array}{c}3^{\text {er }} S Y \\
(n=53)\end{array}$ & $\begin{array}{c}4^{\text {to }} S Y \\
(n=48)\end{array}$ & $\begin{array}{l}5^{\text {to }} S Y \\
(n=45)\end{array}$ & $\begin{array}{l}6^{\text {to }} S Y \\
(n=40)\end{array}$ \\
\hline Age (years) & $\begin{array}{l}\leq 20 \\
>20 \\
\text { Average (years) }\end{array}$ & $\begin{array}{c}121(88 \%) \\
16(12 \%) \\
19\end{array}$ & $\begin{array}{c}41(79 \%) \\
11(21 \%) \\
20\end{array}$ & $\begin{array}{c}28(53 \%) \\
25(47 \%) \\
21\end{array}$ & $\begin{array}{c}16(33 \%) \\
32(67 \%) \\
21\end{array}$ & $\begin{array}{c}0 \\
45(100 \%) \\
23\end{array}$ & $\begin{array}{c}0 \\
40(100 \%) \\
24\end{array}$ \\
\hline Gender & $\begin{array}{l}\text { Male } \\
\text { Female }\end{array}$ & $\begin{array}{l}58(42 \%) \\
79(58 \%)\end{array}$ & $\begin{array}{l}24(46 \%) \\
28(54 \%)\end{array}$ & $\begin{array}{l}28(53 \%) \\
25(47 \%)\end{array}$ & $\begin{array}{l}23(48 \%) \\
25(52 \%)\end{array}$ & $\begin{array}{l}28(62 \%) \\
17(38 \%)\end{array}$ & $\begin{array}{l}24(60 \%) \\
16(40 \%)\end{array}$ \\
\hline Resindence & $\begin{array}{l}\text { Abroad } \\
\text { Local }\end{array}$ & $\begin{array}{l}26(19 \%) \\
111(81 \%)\end{array}$ & $\begin{array}{l}18(35 \%) \\
34(65 \%)\end{array}$ & $\begin{array}{l}17(32 \%) \\
36(68 \%)\end{array}$ & $\begin{array}{c}8(17 \%) \\
40(83 \%)\end{array}$ & $\begin{array}{c}6(13 \%) \\
39(87 \%)\end{array}$ & $\begin{array}{l}10(25 \%) \\
30(75 \%)\end{array}$ \\
\hline Work & $\begin{array}{l}\text { Yes } \\
\text { No }\end{array}$ & $\begin{array}{c}13(9 \%) \\
124(91 \%)\end{array}$ & $\begin{array}{c}4(8 \%) \\
48(92 \%)\end{array}$ & $\begin{array}{c}6(11 \%) \\
47(89 \%)\end{array}$ & $\begin{array}{c}2(4 \%) \\
46(96 \%)\end{array}$ & $\begin{array}{c}8(18 \%) \\
37(82 \%)\end{array}$ & $\begin{array}{c}8(20 \%) \\
32(80 \%)\end{array}$ \\
\hline Extracurricular activities & $\begin{array}{l}\text { Sports } \\
\text { Music } \\
\text { Language study } \\
\text { School groups } \\
\text { Not specified } \\
\text { No }\end{array}$ & $\begin{array}{c}10(7 \%) \\
2(1 \%) \\
2(1 \%) \\
7(5 \%) \\
4(3 \%) \\
111(81 \%)\end{array}$ & $\begin{array}{c}2(4 \%) \\
2(4 \%) \\
0 \\
2(4 \%) \\
0 \\
46(88 \%)\end{array}$ & $\begin{array}{c}6(11 \%) \\
2(4 \%) \\
3(6 \%) \\
7(13 \%) \\
1(2 \%) \\
34(64 \%)\end{array}$ & $\begin{array}{c}7(15 \%) \\
1(2 \%) \\
1(2 \%) \\
8(17 \%) \\
2(4 \%) \\
29(60 \%)\end{array}$ & $\begin{array}{c}5(11 \%) \\
0 \\
4(9 \%) \\
9(20 \%) \\
1(2 \%) \\
26(58 \%)\end{array}$ & $\begin{array}{c}2(5 \%) \\
0 \\
1(2 \%) \\
1(2 \%) \\
1(2 \%) \\
35(87 \%)\end{array}$ \\
\hline Academic hours & $\begin{array}{l}\leq 5 \\
>5\end{array}$ & $\begin{array}{c}27(20 \%) \\
110(80 \%)\end{array}$ & $\begin{array}{c}6(12 \%) \\
46(88 \%)\end{array}$ & $\begin{array}{c}5(9 \%) \\
48(91 \%)\end{array}$ & $\begin{array}{c}7(15 \%) \\
41(85 \%)\end{array}$ & $\begin{array}{l}19(42 \%) \\
26(58 \%)\end{array}$ & $\begin{array}{c}0 \\
40(100 \%)\end{array}$ \\
\hline Extracurricular studies & $\begin{array}{l}\text { Currently yes } \\
\text { Currently no }\end{array}$ & $\begin{array}{c}31(23 \%) \\
106(77 \%)\end{array}$ & $\begin{array}{c}8(15 \%) \\
44(85 \%)\end{array}$ & $\begin{array}{c}6(11 \%) \\
47(89 \%)\end{array}$ & $\begin{array}{c}9(19 \%) \\
39(81 \%)\end{array}$ & $\begin{array}{l}10(22 \%) \\
35(78 \%)\end{array}$ & $\begin{array}{c}3(8 \%) \\
37(92 \%)\end{array}$ \\
\hline Lecturer activities & $\begin{array}{l}\text { I attend } \\
\text { I do not attend }\end{array}$ & $\begin{array}{c}19(14 \%) \\
118(86 \%)\end{array}$ & $\begin{array}{l}16(31 \%) \\
36(69 \%)\end{array}$ & $\begin{array}{l}11(21 \%) \\
42(79 \%)\end{array}$ & $\begin{array}{l}13(27 \%) \\
35(73 \%)\end{array}$ & $\begin{array}{l}13(29 \%) \\
32(71 \%)\end{array}$ & $\begin{array}{l}13(33 \%) \\
27(67 \%)\end{array}$ \\
\hline Hours of daily sleep & $\begin{array}{l}<7 \\
\geq 7 \\
\text { Average }\end{array}$ & $\begin{array}{c}92(67 \%) \\
45(33 \%) \\
6\end{array}$ & $\begin{array}{c}26(50 \%) \\
26(50 \%) \\
6\end{array}$ & $\begin{array}{c}38(72 \%) \\
15(28 \%) \\
6\end{array}$ & $\begin{array}{c}39(81 \%) \\
9(19 \%) \\
6\end{array}$ & $\begin{array}{c}37(82 \%) \\
8(18 \%) \\
6\end{array}$ & $\begin{array}{c}40(100 \%) \\
0 \\
5\end{array}$ \\
\hline Addictive Habits & $\begin{array}{l}\text { Alcohol } \\
\text { Tobacco } \\
\text { Not specified } \\
\text { No }\end{array}$ & $\begin{array}{c}1(1 \%) \\
6(4 \%) \\
8(6 \%) \\
122(89 \%)\end{array}$ & $\begin{array}{c}0 \\
2(4 \%) \\
5(10 \%) \\
45(86 \%)\end{array}$ & $\begin{array}{c}4(8 \%) \\
0 \\
5(9 \%) \\
44(83 \%)\end{array}$ & $\begin{array}{c}2(4 \%) \\
1(2 \%) \\
17(36 \%) \\
28(58 \%)\end{array}$ & $\begin{array}{c}2(4 \%) \\
2(4 \%) \\
11(25 \%) \\
30(67 \%)\end{array}$ & $\begin{array}{c}5(12 \%) \\
5(12 \%) \\
0 \\
30(75 \%)\end{array}$ \\
\hline Use of Antidepressants & $\begin{array}{l}\text { Yes } \\
\text { No }\end{array}$ & $\begin{array}{c}4(3 \%) \\
133(97 \%)\end{array}$ & $\begin{array}{c}1(2 \%) \\
51(98 \%)\end{array}$ & $\begin{array}{c}2(4 \%) \\
51(96 \%)\end{array}$ & $\begin{array}{c}2(4 \%) \\
46(96 \%)\end{array}$ & $\begin{array}{c}1(2 \%) \\
44(98 \%)\end{array}$ & $\begin{array}{c}2(5 \%) \\
38(95 \%)\end{array}$ \\
\hline
\end{tabular}

The variables of "Marital status" and "Children"' were eliminated since the answers were in a significant majority (373 participants in each of the variables) "Single" and "I have no children." The lecturer activities included in the survey attached to the MBI-SS were courses, diplomas, seminars, and conferences. The answer "Other" attached to the sections "Extracurricular activities" and "Addictive habits" was removed as it was not indicated as an adequate response in any SY. The description of the section on "Daily sleep hours" received a verbally informed modification to the surveyed students within the 6th SY group given that their sleep schedule is modified by various factors such as hospital shifts, rotations, and theoretical-practical classes, concluding that $100 \%$ get $<7$ hours of sleep, with an average of $5 \mathrm{~h} /$ day distributed around the day (not constant). Although the use of antidepressants was included in the survey, it did not represent an exclusion criterion for this research.

SY: school year

A statistical analysis using the ANOVA test was conducted for an average comparison of the MBI-SS subscales between SYs. The results with a significant difference are included in table 4 . This table shows a greater amount of differences within the FOC subscale compared to the other subscales.

The reliability analysis was conducted through the Cronbach's Alpha coefficient (Table 5), said values presenting acceptable levels of internal consistency for the scale and its respective subscales (RPA, OEE, and FOC).

\section{Discussion}

Undergraduate medical students are constantly exposed to high levels of stress, even before their clinical internship ${ }^{16}$.

Results identify considerable differences between the analyzed variables within socio-demographic characteristics and abnormally high FOC values found in participants in the group in their $6^{\text {th }}$ SY, which is the SY with the heaviest physical and mental workload because of its theoretical-practical activities in the clinical 
Table 2. Descriptive statistical values of the subscales of the MBI-SS

\begin{tabular}{|c|c|c|c|}
\hline & & Average & $\sigma$ \\
\hline & RPA & 25.28 & 5.04 \\
\hline \multirow[t]{3}{*}{ First SY } & OEE & 14.73 & 6.1 \\
\hline & FOC & 2.21 & 3.44 \\
\hline & EFI & 26.31 & 6.38 \\
\hline \multirow[t]{3}{*}{ Second SY } & OEE & 14.69 & 6.47 \\
\hline & FOC & 1.35 & 1.97 \\
\hline & RPA & 27.28 & 6.38 \\
\hline \multirow{3}{*}{ Third SY } & OEE & 17.68 & 6.3 \\
\hline & FOC & 2.43 & 2.68 \\
\hline & RPA & 25.85 & 6.57 \\
\hline \multirow[t]{3}{*}{ Fourth SY } & OEE & 14.85 & 7.59 \\
\hline & FOC & 3.49 & 3.6 \\
\hline & RPA & 25.87 & 5.21 \\
\hline \multirow[t]{3}{*}{ Fifth SY } & OEE & 13.98 & 6.33 \\
\hline & FOC & 4.51 & 5.18 \\
\hline & RPA & 25 & 6.79 \\
\hline \multirow[t]{2}{*}{ Sixth SY } & OEE & 16.11 & 6.57 \\
\hline & FOC & 5 & 5.68 \\
\hline
\end{tabular}

Descriptive analysis of mean scores obtained by subscale of the MBI-SS divided by SY, in addition to values of $\sigma$. The demonstrated $\sigma$ values of the FOC subscale demonstrate a generally lower value compared to the RPA and OEE scales. This indicates a smaller dispersion between the values answered in the MBI-SS. SY: school year; $\sigma$ : standard deviation

field ${ }^{22}$. Values such as "Academic schedule" and a low number of average sleeping hours were identified in this study as the most demanding; therefore, they did not cause a considerable increment in BOS cases, they did produce abnormalities in their respective subscales in the $6^{\text {th }}$ SY. The rest of the variables analyzed in table 1 are included because they are considered to cause stress or anxiety and are mentioned in the literature as such.

The FOC subscale proved to have quite different levels between SYs; this can be found in the literature as well ${ }^{23}$. Not surprisingly, the FOC subscale in the $6^{\text {th }}$ SY showed a greater difference versus the other SYs, since it seemed to be the most affected by the hospital-service continuous duration effect, which these students performed in greater amounts while advancing school degrees. The $6^{\text {th }}$ year of medicine school (described as the medical internship with the highest workload by students of the evaluated institution) demands that these be completed given the academic consequences, which may prevent the student from finishing medicine school; this resulted in an additional source of stress. These abnormal levels of FOC were accompanied by abnormal levels of OEE as a direct cause of the presence of FOC ${ }^{9}$.

An analysis of the percentiles which were defined in this study as the abnormal values of the subscales of the MBI-SS was conducted on each of the SYs. The percentage of cases evaluated as abnormal in the FOC subscale was similar to the rest of the Sys. This is a result of the way, we defined a value as abnormal based on the same results of each SY separately, thus, we need to take into consideration the results of the obtained percentiles, which indicated a greater numeric value (indicating abnormality) as SYs increased, with the exception of the $1^{\text {st }}$ year, suggesting that despite the fact that the students were in their first SY, they came to manage high stress levels compared to the following years because of the adaptation period to university life ${ }^{24}$. On the other hand, when performing the same analysis on RPA and OEE, there was no significant difference between SYs, which indicates that even though the physical and mental workload which the medical internship imposes influenced the attitude of the student, it did not influence his/her perception of themselves (RPA) ${ }^{25}$ and affected OEE only minimally.

In the OEE, subscale we are able to see elevated levels in the $6^{\text {th }}$ SY, nevertheless, we did not observe the same increase when advancing to the next SYs, since OEE levels during the $5^{\text {th }}$ SY were lower compared to those of the previous years, sharing similarities with the observed data during the $2^{\text {nd }} S Y$ being lower than those in the $1^{\text {st }}, 3^{\text {rd }}$, and $4^{\text {th }}$ years. We attribute this to specific characteristics of the course given, since it is a flexible schedule with little clinical activity despite of the progress of these students ( $\left.5^{\text {th }} \mathrm{SY}\right)$.

When analyzing the three subscales that comprise the MBI-SS, we obtained as a result, altogether, the BOS prevalence within a population. Unfortunately, given the inaccuracy regarding the interpretation of the MBI-SS questionnaire, it was difficult to perform a comparison with similar studies. Nevertheless, a study with a similar procedure to ours obtained a $2.4 \%$ in general prevalence within a finite population ${ }^{20}$, which contrasted with our result of a general $7 \%$. Taking into consideration the divisions created between SYs, no great 


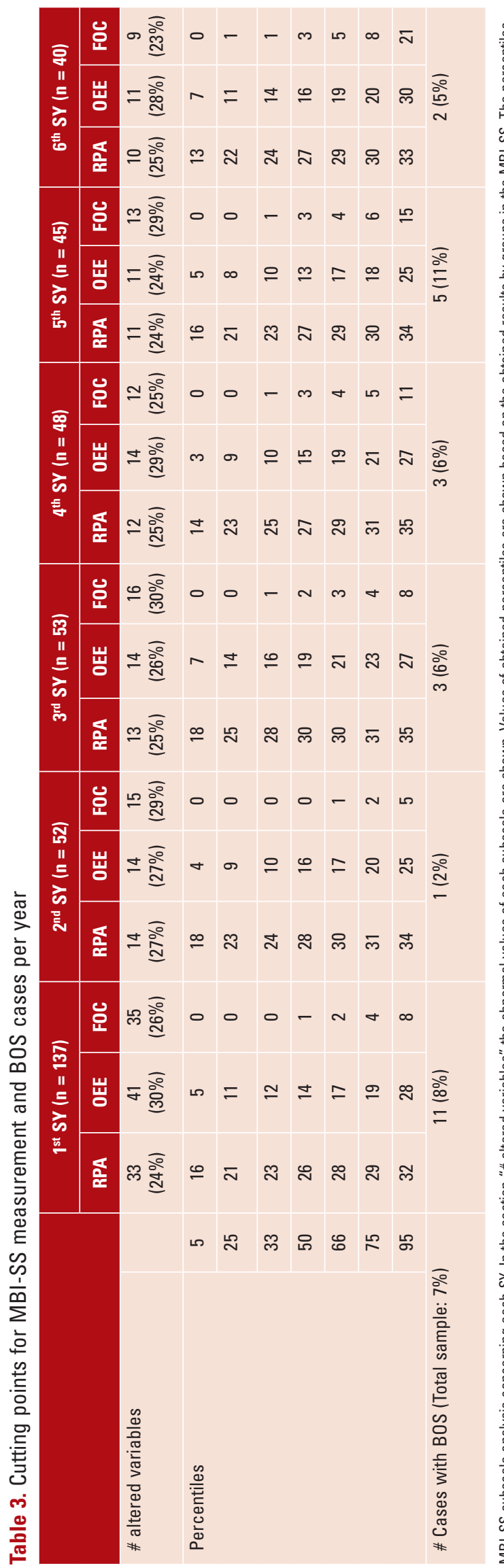

difference was obtained, contrary from what the subscales OEE and FOC may let us suppose. A BOS predominance in the last SYs did not exist, given the lack of abnormality in the RPA subscale. The $5^{\text {th }}$ year obtained the greatest percentage of what should properly be called BOS, which could possibly be attributed to the high academic degree that this year brings, in addition to the fact that it is considered the immediate prior period to medical internship, with everything that entails.

Barlem JG, et al. ${ }^{26}$, mentions a significant abnormal level within the RPA variable in the second half of the course of the entirety of the academic course of our medical school, given a greater amount of extracurricular activities, compared to the previous SYs. However, this did not occur in our study despite the fact that in our population, there was an increase in extracurricular activities the higher the SY.

This study determined that SY did in fact influence the presence of BOS; while not exactly what we call BOS, this factor affected values on every scale separately. Current literature shows varied numbers concerning BOS prevalence among university students, especially medical students. In Latin America, values range from $2.4 \%$ to $56.9 \% 4,10,20,27$; therefore, we consider that our institution $(7 \%)$ is under similar values to those of existent evidence.

Concerning the internal consistency report of MBI-SS thanks to Cronbach's alpha coefficient, which represents a standard practice for the presentation of the degree of reliability of said scores ${ }^{20}$, we obtained a significant level of reliability, which is recommended to be between 0.70 and $0.95^{28}$. This will contribute to the standardization and interpretation of the survey.

\section{Limitations}

We did not find records which evaluate the onset of BOS by SY similarly to that of this study. Moreover, there was a need to comparing academic programs similar to the one used in this research to know the variables that condition $\mathrm{BOS}$ onset more clearly.

A comparative study between SYs was also necessary in undergrads, as well as in the SYs linked to medical residencies and hospital job positions to define those variables which cause physical and mental deterioration between med students, residents, and health professionals ${ }^{29}$, and thus, discover any changes between these two groups which may be present, and organize effective strategies to prevent BOS in these students. 
Table 4. MBI-SS subscale correlation between Sys

\begin{tabular}{|c|c|c|c|}
\hline & SY & $n$ & p \\
\hline \multirow[t]{2}{*}{ RPA } & 1 & 137 & \multirow[t]{2}{*}{0.01} \\
\hline & 3 & 53 & \\
\hline \multirow[t]{2}{*}{ OEE } & 1 & 137 & \multirow[t]{2}{*}{0.02} \\
\hline & 3 & 53 & \\
\hline \multirow[t]{2}{*}{ OEE } & 3 & 53 & \multirow[t]{2}{*}{0.02} \\
\hline & 5 & 45 & \\
\hline \multirow[t]{2}{*}{ FOC } & 1 & 137 & \multirow[t]{2}{*}{0.04} \\
\hline & 5 & 45 & \\
\hline \multirow[t]{2}{*}{ FOC } & 1 & 137 & \multirow[t]{2}{*}{0.02} \\
\hline & 6 & 40 & \\
\hline \multirow[t]{2}{*}{ FOC } & 2 & 52 & \multirow[t]{2}{*}{0.04} \\
\hline & 4 & 48 & \\
\hline \multirow[t]{2}{*}{ FOC } & 2 & 52 & \multirow[t]{2}{*}{0.006} \\
\hline & 5 & 45 & \\
\hline \multirow[t]{2}{*}{ FOC } & 2 & 52 & \multirow[t]{2}{*}{0.004} \\
\hline & 6 & 40 & \\
\hline
\end{tabular}

Values whose $p$ value was significant. The rest of the values obtained by the general comparison between means that are not reflected in this table should be interpreted as values whose difference was not significant. A greater number of differences are observed within the FOC subscale, with respect to the other subscales of the MBI-SS.

SY: school year

Table 5. Cronbach's alpha for MBI-SS

\begin{tabular}{|l|c|c|}
\hline & Cronbach's alpha & \# of items \\
\hline RPA & 0.84 & 6 \\
\hline OEE & 0.858 & 5 \\
\hline FOC & 0.888 & 4 \\
\hline
\end{tabular}

General report of internal consistency of MBI-SS applied to our sample

\section{Conclusions}

BOS prevalence in students was $7 \%$ among the studied population. We were able to determine through this study that the SY has a mild influence on the presence of BOS and said influence stands out when specifically evaluating the FOC subscale of the MBI-SS.

\section{Conflicts of interest}

The authors declare not to have any conflicts of interest in this study.

\section{Funding}

The present research did not receive any specific scholarship from any agency, public, commercial, or non-profit.

\section{Ethical disclosures}

Protection of human and animal subjects. The authors declare that no experiments were performed on humans or animals for this study.

Confidentiality of data. The authors declare that they have followed the protocols of their work center on the publication of patient data.

Right to privacy and informed consent. The authors declare that no patient data appear in this article.

\section{References}

1. Vélez NS. Historical and conceptual elements of burnout syndrome. Hosp Gen Ticomán. 2016:18:51-3.

2. Freudenberger HJ. Staff burn-out. J Soc Issues. 1974;90:159-65.

3. Leka BA. La Organización Del Trabajo y el Estrés. England: Universidad de Nottingham; 2004.

4. Díaz Narváez V. Prevalencia y perfil del síndrome de burnout en el personal de salud de la Clínica Alemana de Puerto Varas. Rev GPU. 2010;2:230-3.

5. Zuluaga CM, Moreno M. Relación entre síndrome de burnout, estrategias de afrontamiento y engagement. Psicol Desde Caribe. 2012;29:205-27.

6. Ricardo YR. Estudio unidimensional del síndrome de burnout en estudiantes de medicina de Holguín. Rev Asoc Esp Neuropsiquiatría. 2012;32:795-803.

7. Maslach C, Schaufeli WB, Leiter MP. Job burnout. Annu Rev Psychol. 2001:52:397-422.

8. Bria M, Spânu F, Adriana B, Dumitras DL. Maslach burnout inventory-general survey: factorial validity and invariance among Romanian healthcare professionals. Burn Res. 2014;1:103-11.

9. Maslach C, Goldberg J. Prevention of burnout: new perspectives. Appl Prev Psychol 1998;74:63-74.

10. Castro JA, López LE, Vela CS, Garcia MO, Ramírez L, Ruiz JM, et al. Síndrome de burnout en estudiantes universitarios: tendencias actuales. J Faculty Med. 2016;16:333.

11. Agudelo SA, Castrillón JJ, Restrepo CJ, Aguilar DP, Henao AF, Cala ML. Síndrome de burnout, y factores asociados en estudiantes de I a X semestre de la facultad de medicina de la universidad de Manizales (Colombia). Arch Med. 2009;10:10-126.

12. Ávila IY, Orozco J, Alvis LR. Síndrome de burnout en el personal médico de una institución prestadora de servicios de salud de Cartagena de Indias. Rev Univ Ind Santander. 2015;47:187-92.

13. Bore M, Kelly B, Nair B. Potential predictors of psychological distress and well-being in medical students: a cross-sectional pilot study. Adv Med Educ Pract. 2016:7:125-35

14. Jackson ER, Shanafelt TD, Hasan O, Satele DV, Dyrbye LN. Burnout and alcohol abuse/dependence among U.S. Medical students. Acad Med. 2016;91:1251-6.

15. Jadoon NA. Anxiety and depression among medical students: a cross-sectional study. J Pak Med Assoc. 2010;60:699-702.

16. Garza MR, Salazar MF. El estrés en estudiantes de medicina al inicio y final de su formación académica. Rev Iberoam Educ. 2014:66:105-22.

17. Dahlin M, Joneborg N. Stress and depression among medical students: a cross-sectional study. Med Educ. 2005;39:594-604.

18. Rotenstein LS, Ramos MA, Torre M. Prevalence of depression, depressive symptoms, and suicidal ideation among medical students a systematic review and meta-analysis. JAMA. 2016;316:2214-36.

19. Lozada JP. Salud Mental en Estudiantes de Medicina: depresión, Estrés, Burnout, Suicidio. Ecuador: AAEMPI; 2017.

20. Martínez $\mathrm{CH}$, Domínguez CC. Validación del cuestionario Maslach burnout inventory-student survey (MBI- SS) en contexto académico colombiano. CES Psicol. 2016:9:1-15.

21. Alonso JG, Pazmino M. Cálculo e interpretación del Alfa de cronbach para el caso de validación de la consistencia interna de un cuestionario, con dos posibles escalas tipo Likert. Rev Publicando. 2015;2:62-77. 
22. Erika M, Godeleva O, Ortiz R, Martínez AJ. Burnout en estudiantes de pregrado de medicina y su relación con variables de personalidad. Ter Psicol. 2014;32:235-42.

23. Arata MF, Soto CM. Error de medición alrededor de los puntos de corte en el mbi-gs measuring error around the cutting points in the mbi-gs. Liberabit. 2014;20:209-18.

24. Toews JA, Lockyer JM, Dobson DJ, Brownell AK. Stress among residents, medical students, and graduate science $(\mathrm{MSc} / \mathrm{PhD})$ students. Acad Med. 1993;68:S46-8.

25. Rosa M, Isabel M. Antecedentes de la autoeficacia en profesores y estudiantes universitarios: un modelo causal. Rev Psicol Trab Organ. 2005:21:59-176.
26. Barlem JG, Lunardi VL, Lunardi GL, Barlem EL, Silveira RS, Vidal DA. Burnout syndrome among undergraduate nursing students at a public university. Rev Latinoam Enferm. 2014;22:934-41.

27. Lopez LA, Celis GD, Maciel VC. Síndrome de burnout en estudiantes de primero a sexto año de medicina en una universidad privada del norte de Mexico. Medwave. 2016;16:e6432.

28. Tarakol M, Dennick R. Making sense of cronbach's alpha. Int J Med Educ. 2011;2:53-5

29. Muñoz HC, Martínez FJ, Gómez-Alonso C, Valladares PC. Burnout syndrome in family medicine residents. Arch Med Fam. 2018; 20:103-10. 